\title{
The Effectiveness of Project-Based Learning Models in Improving Students' Creativity (A Literature Review)
}

\author{
Ni Ketut Cendy Cahyani \\ Universitas Pendidikan Ganesha, Indonesia \\ cendycahyani2158@gmail.com
}

\begin{abstract}
The learning process on the 2013 curriculum uses a scientific approach that emphasizes students' activity in learning (student-centered learning). Learning that uses a scientific approach needs to be supported by the appropriate model and method. Project-based learning is one of the suggested learning models in the 2013 curriculum (K13). This learning model is designed to engage students in investigating real-world problems in their learning. Project-based learning drives teaching and learning, involves students in the learning process, motivates, and enhances the creativity of students. Hence, project-based learning is the appropriate learning model to improve students' creativity because it requires the students to be directly involved in their learning. Besides, students will also be more interested in learning because the problems used are related to their environment. Thus, the purpose of this paper is sharing the effectiveness of project-based learning model in improving students' creativity.
\end{abstract}

Keywords: 2013 curriculum (K13), creativity, project-based learning

\section{INTRODUCTION}

The 2013 curriculum is a curriculum that applies to the current Indonesian education system. Widayat (2018) stated that the purpose of learning in the 2013 curriculum is to develop the talents, interests and potential of students so that they are characterized and competent. Teachers are required to carry out learning and assessment activities that are relevant to the characteristics of 21 st-century learning so that the 2013 learning objectives can be achieved. 21st-century skills which consist of communication, collaboration, creativity, and critical thinking are expected to be able to be applied to the 2013 curriculum to respond to the increasingly competitive demands of an era (Antasyari, 2018). Then, according to Doringin (2017), the 2013 curriculum emphasizes the importance of 21 st-century skills.

The 21st century is known as the information technology era, globalization era, and industrial revolution 4.0 (Redhana, 2019). Beetham and Sharpe (2013) in (Yu \& Mohammad, 2019) defined 21st-century learning as a reform of education aimed at equipping every student with the basic skills required to meet the challenges of the 21st century. Those $4 \mathrm{C}$ 's elements are essential skills that everyone must master to succeed in facing the challenges, problems, life, and careers of the 21st century (Redhana, 2019). In the era of globalization, the students must be able to become decent communicators, creators, critical thinkers, and collaborators. Hence, teachers must equip and prepare students with 4 C's skills.

One of the important skills needed in the 21 st century is creativity. According to Kaplan (2019), creativity is required in all fields of life. Creativity is essential to survive in the 21st century because it is a provision for someone to live and compete in the global world nowadays. However, many schools do not teach creativity to their 
students. Learning that occurs is still centered on the teacher, where students only listen to the teacher's explanation and do the exercises that are still based on understanding (Prasetya, 2014). Indirectly, students do not have the opportunity to develop their creative thinking skills. Thuan (2018) explained that project-based learning facilitates the teaching and learning process, involves students in the learning process, motivates and encourages the creativity of students. In project-based learning, students are at the center of the learning process (Jalinus et al., 2017). Therefore, project-based learning is one of the appropriate learning models to overcome the problems of students' creativity because it has a scientific approach and student-centered (Yuniarti et al., 2018). In the project-based learning process, the emergence of project work can be seen in the process, creativity, and student activities which will have an impact on improving student learning outcomes (Rati et al., 2017).

Some similar studies related to the implementation of project-based learning in improving the creativity of the students had been conducted. A study that was conducted by Syarifah \& Emiliasari (2019) which investigated the use of project-based learning to develop the abilities and creativity of students in writing narrative text and the perceptions of students in writing subjects of project-based learning implementation. The study showed that project-based learning can help students improve their abilities and creativity in a variety of ways to write narrative text. Another study was done by Ummah et al. (2019). The purpose of this study is describing the implementation of project-based learning model and analyzing the student's creativity improvement in the subject of learning media. The study results showed an improvement in the implementation of project-based learning to students' creativity.

\section{METHOD}

The data for current study was gathered through a literature review. The study was carried out in four steps. The first step was collecting the data. There were two types of resources used in this study, namely primary and secondary resources. Primary resources mean the information gathered about the use of project-based learning to improve students' creativity, while secondary resources mean the data was gathered from certain related books and publications in order to support the current study. The second step was classifying the data related to project-based learning, specifically in improving the creativity of the students. The data was then analyzed to determine the concept of project-based learning and its effectiveness in improving student creativity. The final step was to draw a conclusion, which was done after the data had been analyzed.

\section{FINDINGS \& DISCUSSIONS}

In project-based learning, students are the center of learning who are learning actively to improve their competences. Project-based learning is the method that places students at the center of the learning process (Jalinus et al., 2017). The project task is lifted from the real problems to provide opportunities for students improving their abilities and to understand the implementation of the competence that is being studied. Through project-based learning, according to Indarti (2016), students will learn in-depth ways and respond to the real world. Further, they will learn to think, solve problems, and interact with friends or other people with teachers as facilitators. Liu \& Hsiao (2001) stated that there are six steps in the project-based learning model, namely (1) start with the essential question, (2) design a plan for the project, (3) create a schedule, (4) monitor the students and the progress of the project, (5) assess the outcome, and (6) evaluate the experience. 
In the 21st century, creativity is one of the four essential skills. Creativity is the ability to create something new, the ability to provide new ideas that can be applied in problem-solving, or the ability to see new relationships between pre-existing elements (Nurlela, 2018). Further, creativity emphasizes the process rather than the result. Adam (2006) as cited in (Kivunja, 2015) stated that creativity is essential to be taught because it involves several complex components, namely knowledge, critical thinking, and motivation. To develop students' creativity, teachers need to open up space to them. Teachers need to develop a culture of appreciation for the slightest effort, role or achievement of students so that they will be motivated to continue to improve their achievements (Antasyari, 2018).

According to Sufairoh (2016), the 2013 curriculum aims to prepare Indonesians to be faithful, productive, creative, innovative, affective, and competent to contribute to the life of society, nation, state, and world civilization as individuals and citizens. The 2013 curriculum is a form of development from the previous curriculum, namely the KTSP curriculum which has been implemented by the Indonesian government. With the implementation of the 2013 curriculum, teachers are no longer the center of learning (teacher-centered), but learning is more centered on student activities (student-centered) (Sinambela, 2013).

Some similar studies that support this paper are already conducted. A study that was conducted by Syarifah \& Emiliasari (2019) with an article entitled "ProjectBased Learning to Develop Students' Ability and Creativity in Writing Narrative Story". The purposes of this study were to examine the use of project-based learning to develop the abilities and creativity of students in writing narrative text and the perceptions of students in writing subjects of project-based learning implementation. The results of the study showed that project-based learning can help students improve their abilities and creativity in a variety of ways to write narrative text, including understanding the topic, understanding the genre of narrative, namely social functions, text structure, and language features. In addition, students have a positive view of project-based learning implementation because through PBL, they have learned networking, collaborative learning, and teamwork.

A study entitled 'Creating Manipulatives: Improving Students' Creativity Through Project-Based Learning" was conducted by Ummah et al. (2019). The purpose of this study is describing the implementation of project-based learning model and analyzing the student's creativity improvement in the subject of learning media. This study used a descriptive qualitative method and involved the students who took the learning media course as its subjects. The results of the study showed an improvement in the implementation of project-based learning to students' creativity. Ismuwardani et al. (2019) conducted a study with an article entitled "Implementation of Project Based Learning Model to Increased Creativity and Self-Reliance of Students on Poetry Writing Skills". The purpose of this study was to determine the influence of project-based learning models to increase the creativity and self-reliance of students on the skills of writing poetry. The results of the study showed a significant increase in the implementation of project-based learning to creativity and self-reliance on the skills of writing poetry.

\section{CONCLUSIONS}

From the research result, it can be concluded that project-based learning model can enhance students' creativity in the learning process. Creativity is one of the important skills in curriculum 2013 learning. One learning models that can be used by the teacher to enhance the skill is project-based learning model. The project-based learning model has a scientific approach; hence it is suitable to be implemented in the 
2013 curriculum. In addition, project-based learning model is recommended to be used because it gives an excellent impact on students' creativity. From the three results, it showed that the implementation of project-based learning models could increase students' creativity. All of those studies results are in line with the objectives. It means that project-based learning model can provides an opportunity to improve students' creativity.

\section{REFERENCES}

Antasyari. (2018, November 10). Pembelajaran Abad 21 Dan Kurikulum 2013. Smpnegeri1kalibawang. https://gds2020.com/pembelajaran-abad-21-dankurikulum-2013/amp/

Doringin, F. (2017, August 08). Kurikulum Baru, Ketrampilan Abad 21 dan Implementasinya. Pgsd Binus. https://pgsd.binus.ac.id/2017/08/08/kurikulum-baruketrampilan-abad-21-dan-implementasinya/

Indarti. (2016). Implementing Project-Based Learning ( PBL ) in Final Collection to Improve the Quality of Fashion Design Student. Innovation of Vocational Technology Education, 1, 22-30.

Ismuwardani, Z., Nuryatin, A., \& Doyin, M. (2019). Implementation of Project Based Learning Model to Increased Creativity and Self-Reliance of Students on Poetry Writing Skills. Journal of Primary Education, 8(1), 51-58. https://journal.unnes.ac.id/sju/index.php/jpe/article/view/25229

Jalinus, N., Nabawi, R. A., \& Mardin, A. (2017). The Seven Steps of Project Based Learning Model to Enhance Productive Competences of Vocational Students. Advances in Social Science, Education and Humanities Research, 102(1st International Conference on Technology and Vocational Teachers (ICTVT 2017)), 251-256. https://doi.org/10.2991/ictvt-17.2017.43

Kaplan, D. E. (2019). Creativity in Education: Teaching for Creativity Development. Psychology, 10(02), 140-147. https://doi.org/10.4236/psych.2019.102012

Kivunja, C. (2015). Exploring the Pedagogical Meaning and Implications of the 4Cs "Super Skills" for the 21 st Century through Bruner's 5E Lenses of Knowledge Construction to Improve Pedagogies of the New Learning Paradigm. Creative Education, 06, 224-239. https://doi.org/10.4236/ce.2015.62021

Liu, M., \& Hsiao, Y.-P. (2001). Middle School Students as Multimedia Designers: A Project-Based Learning Approach. National Educational Computing Conference Proceedings, 1-9.

Nurlela, L. (2018). Developing Creative Thinking Skills in Learning at HigherEducational Institution of Teacher. The 3rd UPI International Conference on Technical and Vocational Education and Training (TVET) Developing, March, 114-119. https://doi.org/10.2991/ictvet-14.2015.26

Prasetya, S. P. (2014). Memfasiltasi Pembelajaran Berpusat Pada Siswa. Jurnal Geografi, 12(1), 1-12.

Rati, N. W., Kusmaryatni, N., \& Rediani, N. (2017). Model Pembelajaran Berbasis Proyek, Kreativitas Dan Hasil Belajar MahasiswA. Jurnal Pendidikan Indonesia, 6(1), 60-71.

Redhana, I. W. (2019). Mengembangkan Keterampilan Abad Ke-21 Dalam Pembelajaran Kimia. Jurnal Inovasi Pendidikan Kimia, 13(1), 2239 - 2253.

Sinambela, P. N. J. M. (2013). kurikulum 2013 , guru, siswa, afektif , psikomotorik , kognitif. Jurnal Universitas Negeri Medan, 6(2), 17-29.

Sufairoh. (2016). Pendekatan Saintifik \& Model Pembelajaran K-13. Jurnal Pendidikan Profesional, 5(3), 116-125. 
Syarifah, E. F., \& Emiliasari, R. N. (2019). Project-Based Learning To Develop Students' Ability and Creativity in Writing Narrative Story. Indonesian EFL Journal, 5(1), 85. https://doi.org/10.25134/ieflj.v5i1.1627

Thuan, P. D. (2018). Project-Based Learning: From Theory to FLI Classroom Practice. Proceedings of the 6th International OpenTESOL Conference 2018, 327-339.

Ummah, S. K., In'am, A., \& Azmi, R. D. (2019). Creating Manipulatives: Improving Students ' Creativity Through Project-Based Learning. Journal on Mathematics Education, 10(1), 93-102.

Widayat, W. (2018, September 28). Implementasi Pengembangan Kecakapan Abad 21 Melalui Fitur Kelas Maya Portal Rumah Belajar. Pena Belajar Kemdikbud. http://pena.belajar.kemdikbud.go.id/2018/09/implementasi-pengembangankecakapan-abad-21-melalui-fitur-kelas-maya-portal-rumah-belajar/

Yu, T. X., \& Mohammad, W. M. R. W. (2019). Integration of 21st Century Learning Skills (4C Elements) in Interventions to Improve English Writing Skill Among 3K Class Students. International Journal of Contemporary Education, 2(2), 100-121. https://doi.org/10.11114/ijce.v2i2.4498

Yuniarti, N. N., Susanto, \& Irvan, M. (2018). The Implementation of Scientific Approach with Project Based Learning Model to Improve Students' Analytical Skill and Responds. International Journal of Advanced Engineering Research and Science (IJAERS), 5(10), 90-93. https://doi.org/10.22161/ijaers.5.10.11 